\title{
The presence of anti-nuclear antibodies alone is associated with changes in B cell activation and $T$ follicular helper cells similar to those in systemic autoimmune rheumatic disease
}

Yuriy Baglaenko ${ }^{1,2+}$, Nan-Hua Chang ${ }^{1 \dagger}$, Sindhu R. Johnson ${ }^{3,4,5,6}$, Waleed Hafiz ${ }^{3}$, Kieran Manion ${ }^{1,2}$, Dario Ferri ${ }^{1,2}$, Babak Noamani', Dennisse Bonilla', Sina Rusta-Sellehy', Larissa Lisnevskaia', Earl Silverman ${ }^{8,9}$, Arthur Bookman ${ }^{3,4}$, Carolina Landolt-Marticorena ${ }^{1}$ and Joan Wither ${ }^{1,2,3,4^{*}}$ (D)

\begin{abstract}
Background: Diagnosis of systemic autoimmune rheumatic diseases (SARD) relies on the presence of hallmark antinuclear antibodies (ANA), many of which can be detected years before clinical manifestations. However, ANAs are also seen in healthy individuals, most of whom will not develop SARD. Here, we examined a unique cohort of asymptomatic $\mathrm{ANA}^{+}$individuals to determine whether they share any of the cellular immunologic features seen in SARD.
\end{abstract}

Methods: Healthy ANA ${ }^{-}$controls and $\mathrm{ANA}^{+}$(ANA $\geq 1: 160$ by immunofluorescence) participants with no SARD criteria, with at least one criterion (undifferentiated connective tissue disease (UCTD)), or meeting SARD classification criteria were recruited. Peripheral blood cellular immunological changes were assessed by flow cytometry and transcript levels of BAFF, interferon (IFN)-induced and plasma cell-expressed genes were quantified by NanoString.

Results: A number of the immunologic abnormalities seen in SARD, including changes in peripheral B (switched memory) and T (iNKT, T regulatory, activated memory $T$ follicular helper) subsets and B cell activation, were also seen in asymptomatic ANA ${ }^{+}$subjects and those with UCTD. The extent of these immunologic changes correlated with ANA titer or the number of different specific ANAs produced. Principal component analysis of the cellular data indicated that a significant proportion of asymptomatic $\mathrm{ANA}^{+}$subjects and subjects with UCTD clustered with patients with early SARD, rather than $\mathrm{ANA}^{-}$healthy controls.

Conclusions: ANA production is associated with altered T and B cell activation even in asymptomatic individuals. Some of the currently accepted cellular features of SARD may be associated with ANA production rather than the immunologic events that cause symptoms in SARD.

Keywords: Systemic autoimmune rheumatic disease, Anti-nuclear antibodies, B cell, T cell

\footnotetext{
* Correspondence: Joan.Wither@uhnresearch.ca

tYuriy Baglaenko and Nan-Hua Chang contributed equally to this work.

${ }^{1}$ Krembil Research Institute, University Health Network, 60 Leonard Avenue,

5KD402, Toronto, ON M5T 2S8, Canada

2Department of Immunology, University of Toronto, Toronto, ON, Canada

Full list of author information is available at the end of the article
}

(c) The Author(s). 2018 Open Access This article is distributed under the terms of the Creative Commons Attribution 4.0 International License (http://creativecommons.org/licenses/by/4.0/), which permits unrestricted use, distribution, and

reproduction in any medium, provided you give appropriate credit to the original author(s) and the source, provide a link to the Creative Commons license, and indicate if changes were made. The Creative Commons Public Domain Dedication waiver (http://creativecommons.org/publicdomain/zero/1.0/) applies to the data made available in this article, unless otherwise stated. 


\section{Background}

Within the group of systemic autoimmune rheumatic diseases (SARD), systemic lupus erythematosus (SLE), Sjogren's disease $(\mathrm{SjD})$, systemic sclerosis $(\mathrm{SSc})$, dermatomyositis, and mixed connective tissue disease appear to share a similar pathogenesis based upon their production of anti-nuclear antibodies (ANAs), overlapping clinical features, co-segregation within families, and shared genetic risk variants [1-4]. Studies of patients with SLE and $\mathrm{SjD}$ prior to diagnosis indicate a prolonged pre-clinical phase during which ANAs can be detected in the absence of clinical symptoms [5-8]. While this observation suggests that ANA positivity might serve as a biomarker for SARD development, ANAs are also seen in the healthy population and based upon their prevalence together with that of SARD, it is estimated that $>90 \%$ of $\mathrm{ANA}^{+}$individuals will not progress to SARD.

Following a variable period of asymptomatic ANA positivity, individuals who progress to SLE have the insidious onset of accumulating clinical symptoms, culminating in sufficient criteria for diagnosis $[5,6]$. It is likely that the other SARD have a similar course, since it is not uncommon for individuals to present with positive serologic findings and some clinical symptoms of SARD but insufficient symptoms/signs to make a definitive diagnosis [9-17]. Approximately $20-40 \%$ of these patients go on to develop SARD over the next 3-5 years [11, 13-15]. Although various serologic and cytokine profiles have been reported to be associated with an increased risk of SARD progression [18-22], the cellular immune changes that accompany these serologic/cytokine changes and that distinguish individuals that will eventually progress to SARD from those who will not remain to be determined. In this study, we examined peripheral blood $\mathrm{T}$ and $\mathrm{B}$ cell populations and their activation in asymptomatic $\mathrm{ANA}^{+}$individuals together with patients with undifferentiated connective tissue disease (UCTD) and early SARD to determine whether the cellular immune characteristics found in SARD are distinct from those seen in asymptomatic $\mathrm{ANA}^{+}$individuals, most of whom will not progress to SARD. Surprisingly, several of the cellular changes seen in SARD are also seen in asymptomatic $\mathrm{ANA}^{+}$individuals, suggesting that they are associated with ANA production rather than development of symptoms in SARD.

\section{Methods}

\section{Subjects and data collection}

$\mathrm{ANA}^{+}$subjects were recruited at the Toronto Western and Mount Sinai Hospitals. Patients were typically referred to clinic because of a recently discovered positive ANA test with or without rheumatologic symptoms. All patients were assessed by a participating rheumatologist and the clinical data recorded on a standardized data retrieval form. Individuals with ANA $\geq 1: 160$ were stratified into 3 groups based upon the presence of SARD clinical diagnostic criteria (1997 American College of Rheumatology (ACR) criteria for SLE [23], 2013 ACREuropean League Against Rheumatism (EULAR) criteria for SSc [24], or the revised American-European criteria for SjD [25]): (1) asymptomatic $\mathrm{ANA}^{+}$, no clinical criteria of SARD; (2) UCTD, $\geq 1$ clinical symptom of SARD but insufficient criteria for diagnosis; or (3) early SARD, meeting classification criteria and within 2 years of diagnosis. None of the subjects were on any corticosteroids or disease-modifying antirheumatic drugs (DMARDs), with the exception of anti-malarials. Sex-matched healthy controls (HC) were recruited from hospital/ laboratory personnel and were ANA and specific anti-nuclear antibody negative. Information on family history of SARD or rheumatoid arthritis was ascertained using a validated questionnaire [26]. The study was approved by the Research Ethics Boards of both recruiting hospitals and all participants gave signed informed consent.

\section{Cellular characterization}

Peripheral blood mononuclear cells (PBMCs) were isolated over a Ficoll/Hypaque (GE Healthcare) gradient and treated to remove residual red blood cells (RBCs). Freshly isolated cells $\left(0.5 \times 10^{6}\right)$, or for $\mathrm{T}$ cell intracellular-cytokine expression $1 \times 10^{6}$ cells stimulated with $50 \mathrm{ng} / \mathrm{mL}$ phorbol-12-myristate-13-acetate (PMA) and $500 \mathrm{ng} / \mathrm{mL}$ ionomycin for $4-5 \mathrm{~h}$ in the presence of GolgiStop (BD Biosciences), were stained with various combinations of directly conjugated monoclonal antibodies (mAbs). Antibodies used for staining were mouse anti-human FOXP3-PE (259D/ C7), invariant NKT cell-PE (6B11), CD45RA-PECy7 (HI100), CD3-APC H7 (SK7), CD4-Pacific Blue (RPA-T4), and CD8-PerCPCy5.5 (RPA-T8) from BD Biosciences; and mouse anti-human CD21-FITC (BU32), CD95-FITC (DX2), CXCR5-AlexaFluor488 (J252D4), HELIOS-FITC (22F6), CD24-PE (ML5), CD138-PE (DL-101), IgDPerCPCy5.5 (IA6-2), CD38-PECy7 (HB-7), IgM-APC (MHM-88), CD25-APC (M-A251), CD27-APC/Cy7, CD19-brilliant Violet 421 (HIB19), and CD86-brilliant Violet 605 (IT2.2) from BioLegend. Staining for intracellular FOXP3 and HELIOS was performed according to the protocol from BD Biosciences, using nuclear Cytofix/ Cytoperm solutions. For assessment of T cell intracellular cytokine expression, stimulated cells were first stained for cell surface markers (anti-CD3, anti-CD4, and anti-CD8). The cells were then fixed for $30 \mathrm{~min}$ on ice with Cytofix/ Cytoperm, washed, and stained in Cytoperm with anti-IL-17A-PE (ebio64CAP17, ThermoFisher Scientific) and -IL-21-APC (3A3-N2, BD BioSciences), or anti-IFN$\gamma$-APC (4S.B3, ThermoFisher Scientific) for $30 \mathrm{~min}$ on ice. 
Following further washing, events were acquired using a three-laser LSRII or FACSCanto (BD Biosciences) flow cytometer, with fluorescence-minus-one controls used as negative staining controls. Cells were gated and analyzed using Flow Jo software (TreeStar).

\section{Cytokine measurement}

Total RNA was isolated from whole peripheral blood archived in Tempus tubes (Applied Biosystems) and gene expression was quantified by NanoString using a custom array (nanoString Technologies), as previously described [27]. $\log _{2}$ normalized expression levels of 5 interferon (IFN)-induced genes (EPSTI1, IFI44L, LY6E, OAS3, RSAD2) and 5 plasma cell (PC)-expressed genes (IGHA1, IGJ, IGKV401, IGKC, TNFRSF17) were summed to generate IFN5 and PC5 scores, respectively. Serum IFN- $\alpha$ and $B$ cell activating factor (BAFF) levels were quantified by ELISA, as previously described [27].

\section{Measurement of autoantibodies}

ANAs were quantified by indirect immunofluorescence using the Kallestad $^{\circ}$ Hep-2 kit (BioRad), through the University Health Network laboratory. The Bioplex ${ }^{\circ}$ 2200 ANA Screening System (BioRad) was used to measure the serum levels of 11 specific autoantibodies (anti-dsDNA, anti-chromatin, anti-Ro, anti-La, anti-Sm, anti-SmRNP, anti-RNP, anti-Jo-1, anti-Scl-70, anticentromere and anti-ribosomal $\mathrm{P}$ ), using the company's cutoffs. HC with ANA $\geq 1: 160$ were re-classified into the asymptomatic $\mathrm{ANA}^{+}$group and those with positive ANA $<1: 160$ or any specific autoantibodies were excluded from the study.

\section{Data analysis}

The Kruskal-Wallis test was used for statistical comparisons of differences between $\geq 3$ groups, followed by Dunn's post-test for multiple comparisons. The MannWhitney $U$ test was performed to compare continuous variables between two groups and Fisher's exact test was used to compare discrete variables. The strength of association between variables was determined using Spearman's correlation coefficient. All statistical analyses were performed using GraphPad 6 software (La Jolla, CA, USA) or using various packages in R. Correlation matrices were created using the corrplot (v0.84) package. Principal component analyses (PCA) were performed using the PCA function in the missMDA (v1.12) package, with missing data imputed using the imputePCA function. A total of 10 PCs were calculated. Corresponding plots were created using the scatterplot3d (v0.3-41) package.

\section{Results \\ $\mathrm{ANA}^{+}$individuals lacking a SARD diagnosis have an altered immunologic phenotype}

Demographic and relevant clinical/serologic information for the 187 study participants is shown in Table 1 and (see Additional file 1: Table S1). ANA testing in $\mathrm{ANA}^{+}$ individuals lacking SARD criteria was performed for a variety of reasons including: non-inflammatory arthritis/ arthralgias (41\%, mostly osteoarthritis and fibromyalgia), recruitment to the study as a healthy control (18\%), healthy mother with recurrent miscarriage or child with neonatal lupus (13\%), family history of autoimmunity (7\%), urticaria/non-specific rash (7\%), sicca symptoms in the absence of objective signs of dryness (5\%), fatigue (3\%), or other (7\%). $\mathrm{ANA}^{-} \mathrm{HCs}$ were significantly younger than any of the $\mathrm{ANA}^{+}$groups and a larger proportion of the group was non-Caucasian than in the UCTD and SARD groups (see Additional file 1: Table S1 for additional ethnicity information). There were no significant differences between groups in the proportion of subjects taking anti-malarials. A small number $(n=5)$ of the asymptomatic $\mathrm{ANA}^{+}$individuals were taking anti-malarials at the time of initial evaluation in clinic, which had been started for vague symptoms (fatigue, fibromyalgia) that could not be definitively attributed to SARD. Patients with early SARD had significantly higher ANA titers and a larger number of nuclear antigen autoantibody specificities (as determined by the Bioplex ${ }^{\circ}$ ) when compared with asymptomatic $\mathrm{ANA}^{+}$subjects and subjects with UCTD (Table 1). Additional details on the number and types of ANAs seen in each of the different $\mathrm{ANA}^{+}$groups can be found in Additional file 1: Table S1.

To determine whether $\mathrm{ANA}^{+}$individuals not diagnosed with SARD share any of the immunologic changes seen in SARD, several peripheral blood immune $\mathrm{T}$ and $\mathrm{B}$ cell populations were examined using flow cytometry. Similar to SARD, the number of PBMCs and lymphocytes per milliliter of blood were significantly decreased in asymptomatic $\mathrm{ANA}^{+}$subjects and subjects with UCTD as compared to $\mathrm{ANA}^{-} \mathrm{HC}$ (all $p<0.05$ ). Previous work has shown changes in the proportion and activation of various B cell subsets in SARD [28-37]. Therefore, the proportions of naïve $\left(\operatorname{IgD}^{+} \mathrm{CD} 27^{-}\right)$, unswitched memory $\left(\operatorname{IgD}{ }^{+} \mathrm{CD} 27^{+}\right)$, switched memory $\left(\operatorname{IgD}^{-} \mathrm{CD} 27^{+}\right)$, and double-negative memory $\left(\operatorname{IgD}^{-} \mathrm{CD} 27^{-}\right)$cells within the $\mathrm{CD} 19^{+} \mathrm{B}$ cell population were assessed and the percentage of activated cells within each B cell subset quantified by staining with anti-CD86 or anti-CD95. As previously reported [28], the proportion of naïve $B$ cells was increased in patients with $\mathrm{SSc}$ as compared to $\mathrm{ANA}^{-} \mathrm{HC}$. This was not seen when the SARD population was examined as a whole, reflecting the lack of significant changes in the SLE and $\mathrm{SjD}$ patient subsets. With the exception of a reduction of switched memory 
Table 1 Study participant characteristics

\begin{tabular}{|c|c|c|c|c|c|c|c|c|}
\hline & $\mathrm{HC}$ & Asymptomatic & UCTD & SARD & & & & \\
\hline & $\begin{array}{l}\text { ANA }^{-} \\
N=32\end{array}$ & $\begin{array}{l}\mathrm{ANA}^{+} \\
N=61\end{array}$ & $N=35$ & $\begin{array}{l}\text { Total } \\
N=59\end{array}$ & $\begin{array}{l}\mathrm{SSC} \\
N=19\end{array}$ & $\begin{array}{l}\text { SLE } \\
N=10\end{array}$ & $\begin{array}{l}\mathrm{SjD} \\
N=28\end{array}$ & $\begin{array}{l}\text { DM/MCTD } \\
N=2\end{array}$ \\
\hline Sex: $n$ Female (\%) & $29(91)$ & $59(97)$ & $33(94)$ & $55(93)$ & $17(89)$ & $10(100)$ & $26(93)$ & $2(100)$ \\
\hline Age: mean $\pm S D$ & $35.1 \pm 11.8$ & $44.1 \pm 13.9^{a}$ & $46.5 \pm 16.3$ & $50.7 \pm 13.7$ & $55.1 \pm 12.9$ & $37.3 \pm 10.9$ & $53.0 \pm 12.3$ & 44 \\
\hline Anti-malarials: $n(\%)$ & $0(0)$ & $5(8.2)$ & $8(22.8)$ & $5(8.5)$ & $1(5.3)$ & $2(20)$ & $2(7.1)$ & $0(0)$ \\
\hline Ethnicity: $n$ Caucasian (\%) & $12(37.5)$ & $36(59.0)$ & $24(68.6)$ & $39(66.1)$ & $13(68.4)$ & $5(50)$ & $20(71.4)$ & $1(50)$ \\
\hline Family history: $n(\%)^{\mathrm{b}}$ & $1(3.1)$ & $15(25.9)$ & $7(21.9)$ & $15(26.8)$ & $4(23.5)$ & $1(11.1)$ & $9(31.2)$ & $1(50)$ \\
\hline ANA titer: median & N/A & $1 / 640^{c}$ & $1 / 640^{c}$ & $>1 / 640$ & $>1 / 640$ & $>1 / 640$ & $1 / 640$ & $>1 / 640$ \\
\hline Number of Abs: Mean \pm SD & N/A & $0.74 \pm 1.05^{c}$ & $0.94 \pm 1.17^{c}$ & $1.92 \pm 1.32$ & $1.32 \pm 0.80$ & $2.7 \pm 2.45$ & $2.04 \pm 0.63$ & 2.5 \\
\hline
\end{tabular}

Abbreviations: HC healthy control, ANA anti-nuclear antibody, UCTD undifferentiated connective tissue disease, SARD systemic autoimmune rheumatic disease, SSC systemic sclerosis, SLE systemic lupus erythematosus, SjD Sjogren's disease, DM/MCTD dermatomyositis or mixed connective tissue disease, $N$ number, SD standard deviation, $A b s$ antibodies

${ }^{a}$ Values significantly $(p<0.05)$ different from $\mathrm{ANA}^{-} \mathrm{HC}$ are in bold

${ }^{\mathrm{b}}$ Family history of SARD or rheumatoid arthritis. Percentages are presented as a proportion of those whose family history is known

${ }^{c}$ Significantly $(p<0.05)$ different from SARD

B cells, the proportions of the remaining B cell subsets did not differ between $\mathrm{ANA}^{-} \mathrm{HC}$ and any of the individual SARDs or the SARD population as a whole. In general, the changes seen in the asymptomatic $\mathrm{ANA}^{+}$subjects and subjects with UCTD (Fig. 1a-e) paralleled those seen in patients with early SARD, with both groups demonstrating significant decreases in the proportion of switched memory
B cells and the number of these cells/milliliter of blood (both $p<0.01$ ). There were no differences in the absolute number of cells in the blood for any of the other B cell populations examined, including the transitional $\mathrm{B}$ cell population.

All $\mathrm{ANA}^{+}$individuals, regardless of disease state, had increased expression of the activation marker CD86 on
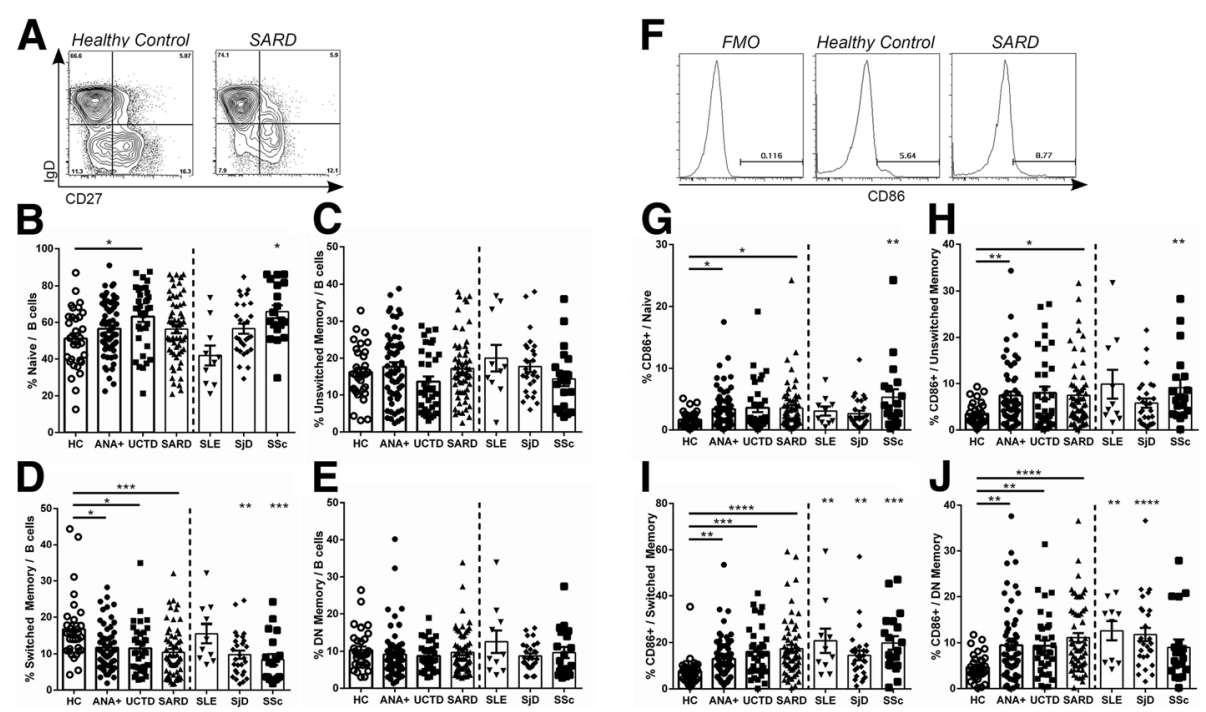

Fig. 1 Asymptomatic anti-nuclear antibodies (ANA) ${ }^{+}$individuals with no diagnosis of systemic autoimmune rheumatic disease (SARD) have abnormalities in peripheral B cell subsets and their activation similar to symptomatic patients with SARD. a Gating strategy for identification of naïve $\left(\operatorname{lgD}{ }^{+} C D 27^{-}\right)$, unswitched memory $\left(\operatorname{lgD}{ }^{+} C D 27^{+}\right)$, switched memory $\left(\operatorname{lgD}{ }^{-} C D 27^{+}\right)$, and double-negative (DN) memory $\left(\operatorname{lgD}{ }^{-} C D 27^{-}\right)$cells within the $\mathrm{CD} 19^{+}$B cell compartment of peripheral blood mononuclear cells from a representative healthy control and a patient with SARD. $\mathbf{b}-\mathbf{e}$ Proportions of the different peripheral B cell subsets within the CD19+ B cell compartment for each subject group. $\mathbf{f}$ Representative gating for $\mathrm{CD}^{+} 6^{+}$cells within the various B cell compartments (example shown is gated on all CD19+ B cells). $\mathbf{g}$-j Proportion of CD86 ${ }^{+}$cells within each of the different peripheral B cell subsets. Statistical comparisons on the left side of each plot are between healthy controls (HC) and asymptomatic $\mathrm{ANA}^{+}$individuals (ANA+), patients with undifferentiated connective tissue disease (UCTD), or pooled patients with SARD, whereas those on the right side of the plot are comparisons between the individual SARDs and HC. Bars represent the mean with SEM. Every data point represents an individual patient. For each set of comparisons statistical significance was determined using the Kruskal-Wallis test with Dunn's post-hoc test for multiple comparisons, as compared to $\mathrm{HC}^{*}{ }^{*} p \leq 0.05,{ }^{* *} p \leq 0.01,{ }^{* * *} p \leq 0.001,{ }^{* * * *} p \leq 0.0001$. SLE, systemic lupus erythematosus; SjD, Sjogren's disease; SSC, systemic sclerosis 
all of their B cell sub-populations. Although there was some variation between the individual SARD conditions in the extent of B cell activation seen in the different B cell subsets, overall the most significant differences as compared to $\mathrm{ANA}^{-} \mathrm{HC}$ were seen in the switched memory and double-negative memory B cell compartments, and this was recapitulated in the asymptomatic $\mathrm{ANA}^{+}$ subjects and subjects with UCTD (Fig. 1f-j). Similar trends were seen for CD95 expression, but in general were not statistically significant (see Additional file 1: Figure S1).

Despite increases in global B cell activation, the frequencies of PC and/or plasmablasts were only significantly elevated in patients with early SLE as compared to $\mathrm{ANA}^{-} \mathrm{HC}$ (see Additional file 1: Figure S2), consistent with previous reports [38]. There was considerable variability in the levels of these cells between individuals within the asymptomatic $\mathrm{ANA}^{+}$and UCTD groups, with a non-significant trend toward increased proportions of plasma cells and/or plasmablasts as compared to HC. This variability did not appear to be due to a lack of consistency in the gating of these populations, as there was a strong correlation between the proportion of PC and/or plasmablasts measured by flow cytometry and genes comprising the PC5 score (see Additional file 1: Figure S2), as reported in other studies [39].

Given the similarity in the B cell phenotype between $\mathrm{ANA}^{+}$subjects with and without a SARD diagnosis, we questioned whether alterations in $\mathrm{T}$ cell regulation/activation were also shared. As previously reported, peripheral iNKT cell frequencies are greatly reduced in the various SARD conditions [40-44]. Similar reductions were seen in the patients with early SARD examined here, and these findings were recapitulated in asymptomatic $\mathrm{ANA}^{+}$subjects and subjects with UCTD (Fig. 2a, b).

Although it was originally proposed that the frequency of $\mathrm{T}$ regulatory (Treg) cells is deceased in SARD, several recent papers have provided data indicating that the proportion of Treg cells is actually increased in SLE and SjD [45-48]. Consistent with these findings, we observed an increased frequency of HELIOS ${ }^{+} \mathrm{FOXP}^{+}{ }^{+}$Treg cells in SLE and SjD and in the early SARD group as a whole, as compared to $\mathrm{ANA}^{-} \mathrm{HC}$. Again, similar trends were seen in $\mathrm{ANA}^{+}$individuals with no SARD diagnosis to those seen in SARD, which was statistically significant in the asymptomatic $\mathrm{ANA}^{+}$group (Fig. 2c, d).

To investigate $\mathrm{T}$ cell activation, we assessed the proportion of PD- $1{ }^{\text {hi }} \mathrm{CXCR} 5^{+} \mathrm{T}$ follicular helper cells (Tfh, Fig. 2e, f), which has been previously shown to reflect activated memory Tfh cells [49], and the proportions of cytokine-producing $\mathrm{T}$ cells (Fig. $2 \mathrm{~g}-\mathrm{j}$ ). Consistent with previous reports of increased activated memory Tfh cells in SLE and SjD [34, 50, 51], the proportion of these cells was significantly increased in both these conditions and in the early SARD group as a whole. Similar but slightly less significant changes were seen in asymptomatic $\mathrm{ANA}^{+}$subjects and subjects with UCTD.

There is considerable disagreement between studies with regard to whether the proportions of various cytokine-producing cells within the $\mathrm{CD} 4^{+} \mathrm{T}$ cell population in the SARD conditions differ from those of healthy controls and if so, whether they are increased or decreased [52-61]. Despite a report indicating that the proportion of peripheral blood IFN- $\gamma$-producing $\mathrm{CD} 4^{+}$ cells in patients with UCTD and SARD are increased as compared to $\mathrm{HC}$ [54], we found that the proportion of these cells was reduced in patients with early SARD, as reported by some groups [56, 58,61], and that a similar trend was seen for the $\mathrm{ANA}^{+}$subjects with no SARD diagnosis, and this was statistically significant in patients with UCTD. The reduced levels of these cells were not accompanied by changes in serum IFN- $\gamma$ (data not shown). No significant differences were seen in the proportions of IL-17-producing and IL-21-producing cells within the peripheral blood in any subject group as compared to $\mathrm{ANA}^{-} \mathrm{HC}$. When the number of cells/milliliter of blood was calculated for each $\mathrm{T}$ cell population, only the reduced proportion of iNKT cells was significant $(p$ $<0.01$ for all $3 \mathrm{ANA}^{+}$groups).

Although we endeavored to age-match, sex-match, and ethnicity-match our $\mathrm{ANA}^{-} \mathrm{HC}$ with the various $\mathrm{ANA}^{+}$ groups, some differences remained. To address whether these differences might have contributed to the differences observed between the $\mathrm{ANA}^{+}$and $\mathrm{ANA}^{-}$groups, we examined the association between these demographic parameters and the cellular phenotypes that were statistically significant. As shown in (see Additional file 1: Figure S3), the majority of the cellular phenotypes did not vary with age. The only exceptions were the percentage of $\mathrm{CD}^{2} 6^{+}$ naive $B$ cells in patients with SARD, which positively correlated with age $(r=0.28, p=0.03)$ and the proportion of iNKT cells, which negatively correlated with age in $\mathrm{ANA}^{-}$ HC $(r=-0.56, p=0.02)$ and patients with SARD $(r=-$ $0.51, p=0.003$ ). The cellular phenotypes also did not vary with ethnicity in $\mathrm{ANA}^{-} \mathrm{HC}$. In asymptomatic $\mathrm{ANA}^{+}$individuals, the proportions of Tfh $(p=0.02)$ and iNKT cells $(p=0.03)$ were slightly increased in non-Caucasians as compared to Caucasians, while in patients with SARD the proportion of $\mathrm{CD}^{2} 6^{+}$cells in the naïve $\mathrm{B}$ cell compartment was decreased in non-Caucasians $(p=0.02)$. With the possible exception of iNKT cells, these trends could not account for the differences observed between groups.

\section{The autoantibody profile correlates independently with the levels of type I IFN and Tfh cells}

As $\mathrm{ANA}^{+}$individuals with no SARD diagnosis had a range of ANA titers and number/type of specific anti-nuclear 

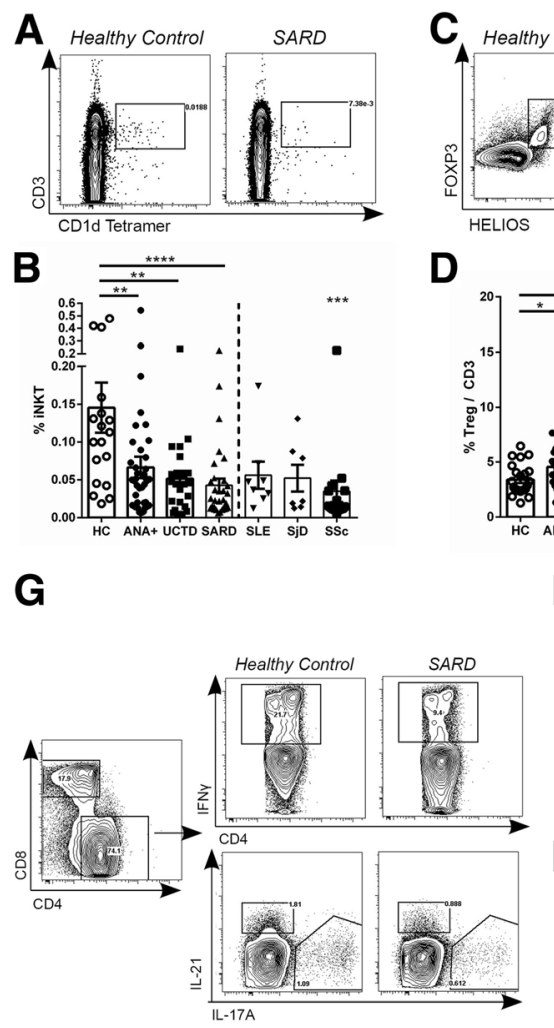

D

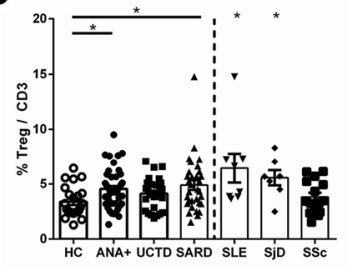

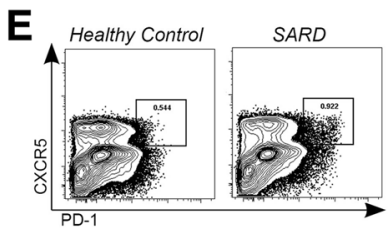

$\mathbf{F}$

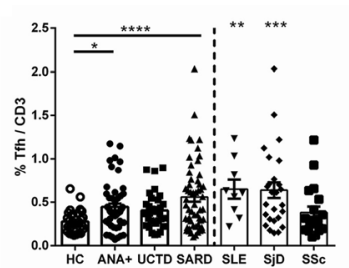

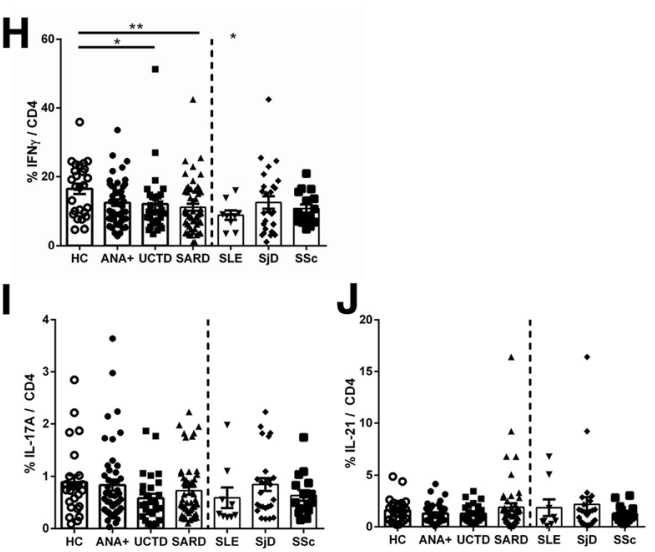

Fig. 2 Reductions in invariant natural killer T (iNKT) cells and increases in T follicular helper (Tfh) and T regulatory (Treg) cells in anti-nuclear antibodies (ANA) ${ }^{+}$individuals regardless of diagnosis. Representative gating, together with scatterplots show frequencies in each subject group for peripheral iNKT $(\mathbf{a}, \mathbf{b})$, Treg $(\mathbf{c}, \mathbf{d})$, and Tfh $(\mathbf{e}, \mathbf{f})$ cells. For the iNKT cell plot, the cells were first gated on lymphocytes, whereas for the Tfh and Treg cell plots, they were first gated on $\mathrm{CD}^{+} \mathrm{CD}^{+}$cells within the lymphocyte pool with the scatterplots showing the percentage of these cells as a proportion of the $\mathrm{CD}^{+} \mathrm{T}$ cell population. $\mathbf{g}$ Representative gating for interferon (IFN)- $\gamma^{-}$, IL-17A-, and IL-21-producing CD4 T cells following phorbol-12-myristate-13-acetate (PMA) and ionomycin stimulation of peripheral blood mononuclear cells (plots shown have been gated on $\mathrm{CD}^{+} \mathrm{CD}^{+}$lymphocytes). $\mathbf{h}$-j Proportions of cytokine-producing cells within the $\mathrm{CD} 3^{+} \mathrm{CD} 4^{+} \mathrm{T}$ cell population for each subject group. Statistical comparisons on the left side of each figure are between healthy controls $(\mathrm{HC})$ and asymptomatic $\mathrm{ANA}^{+}$individuals (ANA+), patients with undifferentiated connective tissue disease (UCTD), or pooled patients with systemic autoimmune rheumatic disease (SARD), whereas those on the right side of the figure are between the individual SARDs and HC. Bars represent the mean with SEM. Every data point represents an individual patient. Statistical significance was determined using the Kruskal-Wallis test with Dunn's post-hoc test for multiple comparisons, as compared to $\mathrm{HC} ;{ }^{*} p \leq 0.05,{ }^{* *} p \leq 0.01,{ }^{* * *} p \leq 0.001,{ }^{* * *} p \leq 0.0001$. SLE, systemic lupus erythematosus; SjD, Sjogren's disease; SSC, systemic sclerosis

antibodies, a Spearman correlation matrix was produced to investigate the association between serologic changes and the peripheral blood cellular profile. BAFF and type I IFN, as measured by peripheral blood gene expression or serum levels, was also included in this analysis, as these cytokines have been proposed to promote immune dysregulation in SARD [62, 63] and we have previously shown that they are elevated in a subset of $\mathrm{ANA}^{+}$individuals with no SARD diagnosis ([27] and Additional file 1: Figure S4).

In asymptomatic $\mathrm{ANA}^{+}$individuals, the ANA titer was negatively correlated with the proportion of switched memory B cells, and positively correlated with markers of activation (CD86 and CD95) in this B cell compartment, and with the proportion of plasma cells, activated memory Tfh, Treg cells, and the levels of type I IFN/ BAFF (Fig. 3). Similar associations were seen for the number of different autoantibody specificities detected by BioPlex ${ }^{\oplus}$, except that there was a negative correlation with the proportion of IFN- $\gamma$-producing $\mathrm{T}$ cells and no correlation with plasma, Tfh, or Treg cells. In patients with early SARD (Fig. 3), no cellular associations were seen with ANA titer. However, patients with early SARD demonstrated the same positive association between the number of autoantibody specificities and the percentage of $\mathrm{CD} 5^{+}$switched memory B cells, proportions of Tfh and Treg cells, and levels of type I IFN/BAFF as was seen in $\mathrm{ANA}^{+}$asymptomatic individuals with ANA titer, arguing that the same immunologic processes are involved in the generation of autoantibodies in symptomatic and 

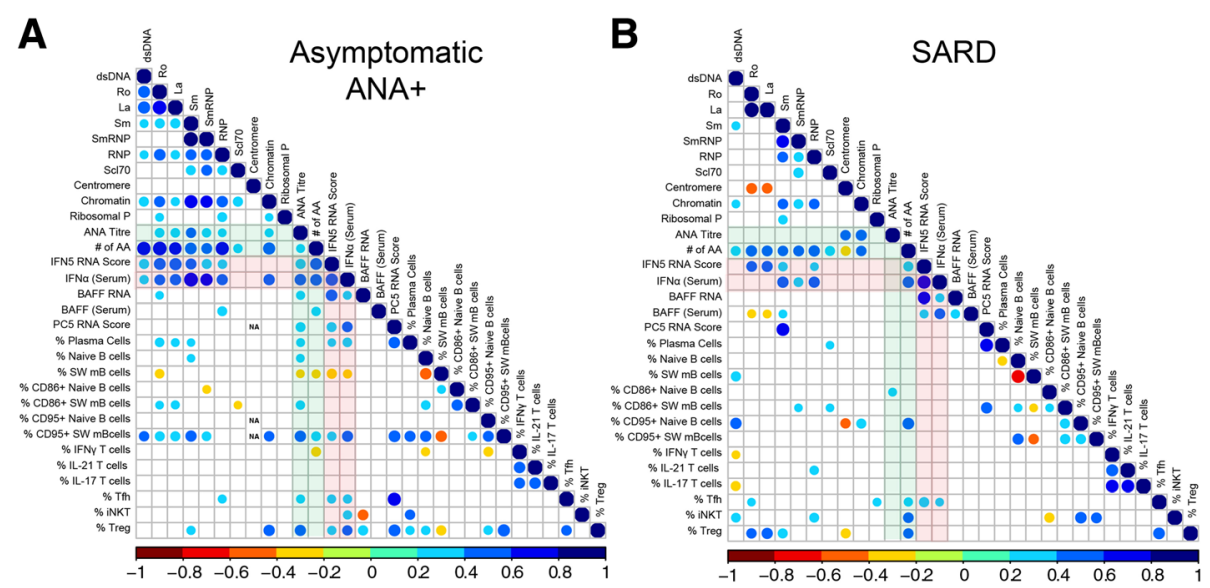

Fig. 3 Correlation between cellular and selected serologic/cytokine phenotypes in asymptomatic anti-nuclear antibodies (ANA) ${ }^{+}$individuals and patients with systemic autoimmune rheumatic disease (SARD). Spearman correlation matrices for asymptomatic ANA ${ }^{+}$individuals (a) and patients with SARD (b). B and T cell populations were gated and defined as outlined in Figs. 1 and 2, plasma cells as outlined in Additional file 1: Figure S3, and $\mathrm{CD}^{+} 5^{+} \mathrm{B}$ cell subpopulations as shown in Additional file 1: Figure S1. The color and size of the dots represents the $\rho$ value, with the scales shown at the bottom of each matrix. Non-significant $(p \geq 0.05)$ correlation is not displayed. IFN, interferon; BAFF, B cell activating factor

asymptomatic individuals. Overall similar but less significant findings were observed in patients with UCTD (see Additional file 1: Figure S5), most likely due to the smaller number of these patients in the cohort.

Since many of the cellular phenotypes appeared to correlate with each other, multivariate analysis was performed to determine which phenotypes were independent predictors of serologic status. When all $\mathrm{ANA}^{+}$subjects were included (those with asymptomatic $\mathrm{ANA}^{+}$, UCTD, and SARD), a model including IFN5 RNA score $(\beta=0.0519, p$ $=2.62 \mathrm{e}-13)$, serum IFN- $\alpha$ levels $(\beta=0.0646, p=1.43 \mathrm{e}-07)$ and the frequency of Tfh cells $(\beta=0.152, p=0.0279)$ best predicted the number of autoantibody specificities. These findings suggest that type I IFNs and Tfh cells independently drive the immune dysregulation that leads to production of multiple autoantibodies in $\mathrm{ANA}^{+}$individuals.

Type I IFNs have been previously reported to promote $B$ cell activation, plasma cell differentiation, Tfh and Th1 cell differentiation, and BAFF production [64-69]. Consistent with the possibility that type I IFNs are driving these cellular abnormalities in $\mathrm{ANA}^{+}$individuals, the IFN5 RNA score and/or serum IFN- $\alpha$ levels were positively associated with CD95 +/- CD86 expression on switched memory B cells, PC5 score, percentage of plasma cells, proportion of activated memory Tfh cells, and BAFF RNA and/or serum levels, particularly in the asymptomatic $\mathrm{ANA}^{+}$and early SARD groups (Fig. 3). Nevertheless, a number of cellular abnormalities were still seen in individuals with normal type I IFN levels (IFN5 score $<2 \mathrm{SD}$ above mean for $\mathrm{ANA}^{-} \mathrm{HC}$ ), including reduced proportions of IFN- $\gamma$-producing $\mathrm{CD} 4^{+} \mathrm{T}$ cells and NKT cells, and increased proportions of $\mathrm{CD}^{2} 6^{+} \mathrm{B}$ cells (Fig. 4), indicating that not all of the cellular abnormalities seen in asymptomatic $\mathrm{ANA}^{+}$individuals are induced by elevated type I IFN. Notably, while there was a trend toward increased proportions of activated memory Tfh cells in asymptomatic $\mathrm{ANA}^{+}$individuals with normal levels of type I IFN, this was not statistically significant.

In contrast to type I IFN, elevated proportions of activated memory Tfh cells were not correlated with the majority of cellular phenotypes. However, in asymptomatic $\mathrm{ANA}^{+}$individuals there was a strong positive association $(p<0.0001, r=0.70)$ between the proportion of activated memory Tfh cells and the PC5 score, suggesting a potential involvement of Tfh cells in the differentiation of autoreactive PC and/or plasmablasts in these individuals.

Although we currently have limited follow-up data on the asymptomatic $\mathrm{ANA}^{+}$individuals in our study, 4 out of 28 subjects who were followed for at least 2 years developed SARD symptoms (myositis $(n=1)$ ), Raynaud's syndrome $(n=1)$, arthritis $(n=1)$, $\operatorname{SLE}(n=1))$ within the 2 years of follow up. While the majority of phenotypes examined did not differ between progressors and non-progressors, the IFN5 scores and serum IFN- $\alpha$ levels were significantly higher $(p=0.023$ and 0.048 , respectively) and there was a trend toward increased activated memory Tfh cells $(p=0.058)$ in progressors, arguing that these processes may also drive the immune dysregulation leading to progression.

There is substantial overlap between the immunologic profiles of $\mathrm{ANA}^{+}$individuals with and without symptoms Since the cellular profiles of $\mathrm{ANA}^{+}$individuals with or without a SARD diagnosis appeared similar on univariate analysis, PCA was performed to determine whether differences between the $\mathrm{ANA}^{+}$groups could be discerned when 

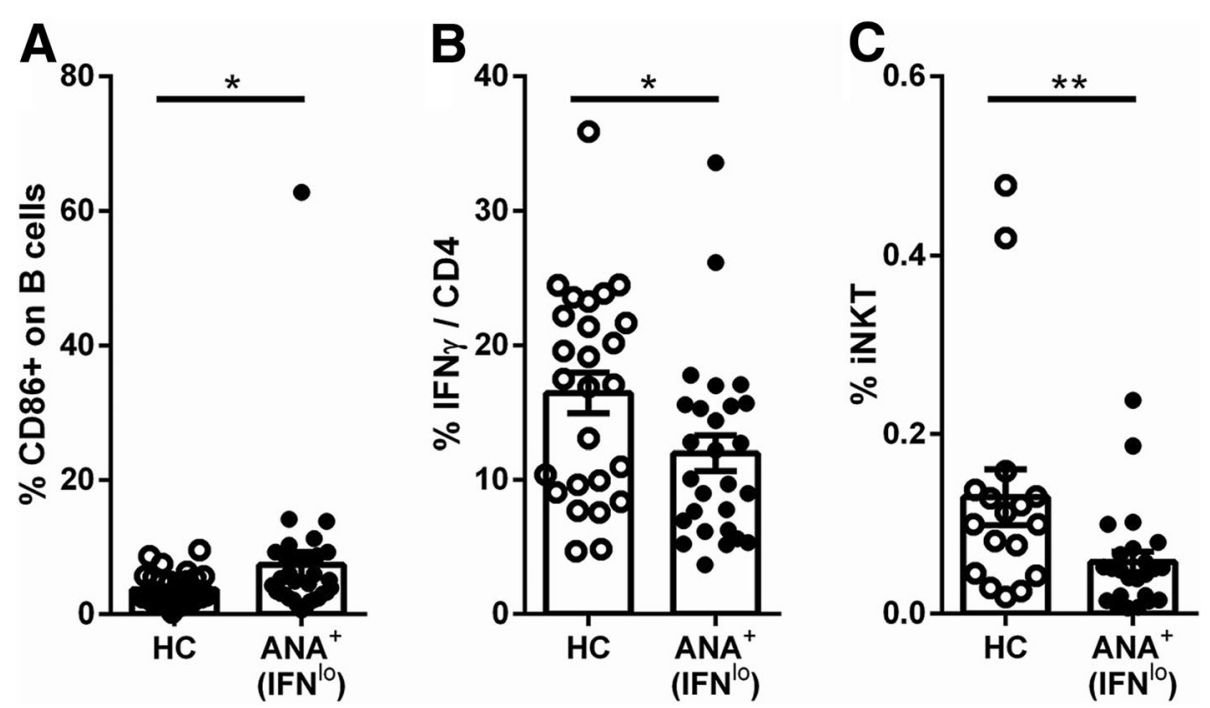

Fig. 4 Cellular immunologic changes seen in asymptomatic anti-nuclear antibodies (ANA) ${ }^{+}$individuals who do not have elevations of type I interferons (IFNs). Asymptomatic ANA $A^{+}$individuals were defined as having normal levels of type I IFNs (IFN ${ }^{\text {lo }}$ ) if their IFN5 score was $<2$ SD above the mean for ANA ${ }^{-}$healthy controls (HC) (all had undetectable levels of serum IFN-a on ELISA). Shown are cellular phenotypes (a \% CD86 ${ }^{+}$B cells (CD86 ${ }^{+}$on B cells), b \% CD4 cells producing IFN- $\gamma$ (IFNy/CD4) and $\mathbf{c} \%$ invariant natural killer T cells (iNKT)) that were significantly different in IFN $N^{10}$ asymptomatic $\mathrm{ANA}^{+}$individuals as compared to $\mathrm{HC}$. Cell populations were defined and gated as outlined in Figs. 1 and 2. Bars represent the mean with SEM. Every data point represents an individual patient. Statistical significance was determined using the Mann-Whitney $U$ test; ${ }^{*} p \leq 0.05,{ }^{* *} p \leq 0.01$

the data were examined as a whole. As shown in Fig. 5, using 3-dimensional PCA analysis incorporating only cellular immunologic phenotypes and the plasma cell RNA signature, largely independent clusters of patients with SARD and $\mathrm{ANA}^{-} \mathrm{HC}$ were identified, with most $\mathrm{ANA}^{-}$ $\mathrm{HC}$ clustered on the lower left in the plots, whereas the majority of the patients with SARD were to the upper right in the plots. While some asymptomatic $\mathrm{ANA}^{+}$subjects and subjects with UCTD appeared to be localized within the region where the majority of $\mathrm{ANA}^{-} \mathrm{HC}$ were clustered on the PCA plot, a substantial number of these individuals $(\sim 50 \%)$ were admixed with the cluster of patients with early SARD , indicating that their cellular abnormalities were remarkably similar to those seen in patients with early SARD.

\section{Discussion}

In this study, we show that $\mathrm{ANA}^{+}$individuals with no SARD symptoms or insufficient symptoms to make a diagnosis have several cellular immunologic changes in their peripheral blood that are very similar to those seen in newly diagnosed patients who satisfy SARD criteria.
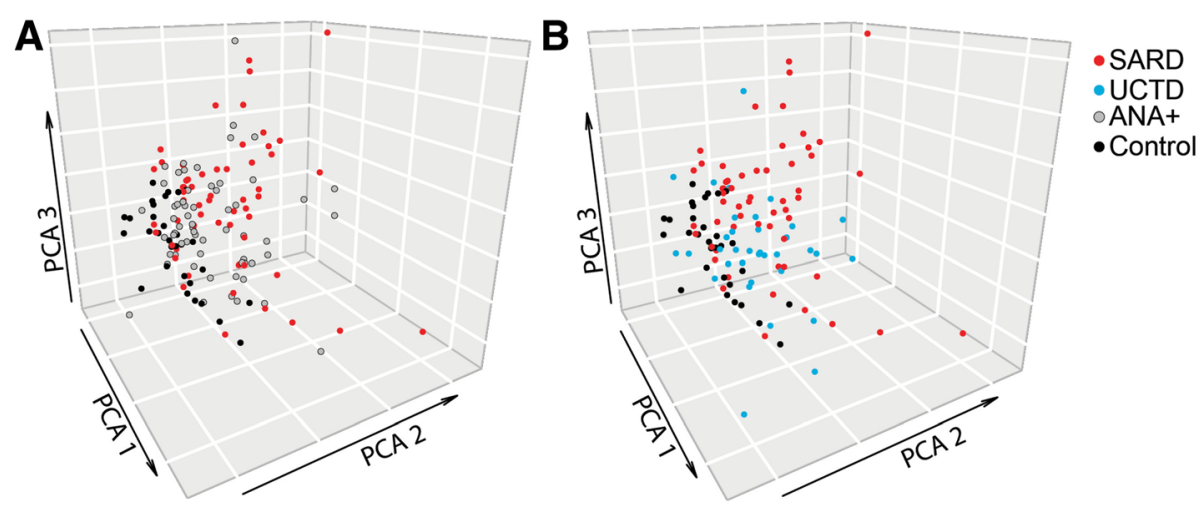

Fig. 5 In principal component analysis (PCA) the cellular phenotype of many asymptomatic anti-nuclear antibody (ANA) $)^{+}$individuals or patients with undifferentiated connective tissue disease (UCTD) overlaps with that of patients with systemic autoimmune rheumatic disease (SARD) and is distinct from that of healthy controls. The 3-D plots show asymptomatic ANA ${ }^{+}$individuals (ANA+, gray) (a) or patients with UCTD (blue) (b), as compared to healthy controls (black) and patients with SARD (red). Analyses were performed using the PCA function in the missMDA (v1.12) package, with missing data imputed using the imputePCA function. Corresponding plots were created using the scatterplot3d (v0.3-41) package 
These findings indicate that some of the cellular abnormalities that are thought to be characteristic of SARD are actually secondary to the immune dysregulation associated with generation of ANAs rather than the immunologic events that accompany the conversion of asymptomatic to symptomatic autoimmunity.

To our knowledge, this is the first study to comprehensively examine the cellular immune features in asymptomatic $\mathrm{ANA}^{+}$individuals and compare them with patients with UCTD and early SARD. A recent study used flow cytometry to compare PBMCs in asymptomatic $\mathrm{ANA}^{-}$and $\mathrm{ANA}^{+}$healthy individuals, but the number of cell populations examined was limited [70]. This study found a small but significant increase in the proportion of memory $\left(\mathrm{CD} 27^{+} \mathrm{CD} 38^{-}\right) \mathrm{B}$ cells and plasmablasts $\left(\mathrm{CD} 27^{+} \mathrm{CD} 38^{+}\right)$in $\mathrm{ANA}^{+}$as compared to $\mathrm{ANA}^{-}$ individuals, suggestive of chronic $\mathrm{B}$ cell activation, but did not examine any activated or specific regulatory $\mathrm{T}$ cell populations. We observed a similar trend toward increased plasma cells and plasmablasts in asymptomatic $\mathrm{ANA}^{+}$individuals, but found that the proportion of class-switched memory B cells was reduced, consistent with several previous studies in SARD [28, 30, 33-37]. It is likely that the apparent disparity in memory B cell findings between the two studies results from the differences in the $B$ cell populations examined, as the $\mathrm{CD} 27^{+} \mathrm{CD} 38^{-}$memory $\mathrm{B}$ cell compartment includes both class-switched and unswitched memory B cell subsets.

There is also a paucity of studies examining the cellular immunologic changes in UCTD. Szordoray et al. found that patients with UCTD and SARD had increased proportions of IFN- $\gamma$-producing $\mathrm{CD}^{+} \mathrm{T}$ cells and decreased proportions of $\mathrm{CD}^{+}{ }^{+} \mathrm{FOXP}^{+} \mathrm{CD} 25^{+} \mathrm{T}$ cells as compared to healthy controls [54]. In a subsequent study, the same group reported an increased ratio of IL-17-producing $\mathrm{CD} 4^{+} \mathrm{T}$ cells to Treg cells in patients with UCTD, with further increases in patients progressing to SARD [71]. Our findings contrast with these results, showing a trend toward decreased proportions of IFN- $\gamma$-producing $\mathrm{CD} 4^{+} \mathrm{T}$ cells and increased proportions of $\mathrm{CD}^{+}{ }^{+} \mathrm{FOXP}^{+}{ }^{+} \mathrm{HELIOS}^{+}$Treg cells in UCTD, both of which were statistically significant in SARD. Currently, the explanation for these differences is unclear. While there were some minor differences between the two studies in the stains used to identify the $\mathrm{T}$ cell populations and in how the data were expressed, analysis of our data using comparable gating still yielded discordant results. Of particular note, although there was a non-significant trend toward a decreased proportion of $\mathrm{CD} 25^{+}$cells within the $\mathrm{CD} 4^{+} \mathrm{FOXP}^{+}{ }^{+} \mathrm{HELIOS}^{+}$Treg cell subset in early SARD ( $\mathrm{ANA}^{-} \mathrm{HC}$ 88.37, asymptomatic $\mathrm{ANA}^{+}$individuals 86.17, patients with UCTD 86.12, patients with SARD 83.53, all $p>0.05$ ), the proportion of
$\mathrm{CD} 4{ }^{+} \mathrm{FOXP} 3^{+} \mathrm{HELIOS}^{+} \mathrm{CD} 25^{+}$cells remained elevated as compared to $\mathrm{ANA}^{-} \mathrm{HC}$, with similar trends seen in asymptomatic $\mathrm{ANA}^{+}$patients $(p<0.05)$ and patients with UCTD.

Our results showing significant increases in the proportion of $\mathrm{CD}^{+}{ }^{+} \mathrm{FOXP}^{+}{ }^{+} \mathrm{HELIOS}^{+}$Treg cells in asymptomatic $\mathrm{ANA}^{+}$individuals and patients with early SARD recapitulate recent findings in SLE and SjD [45, 47, 48], and collectively suggest that ongoing activation of $\mathrm{T}$ cell subsets in $\mathrm{ANA}^{+}$individuals outstrips the capacity of Treg cells to regulate them. These findings are at odds with previous studies suggesting that progression from asymptomatic ANA positivity or UCTD to SARD results from impaired immunoregulation [54, 70, 71]. Indeed, we found that the ratio of cytokine-producing or Tfh cells to Treg cells did not differ between any of the $\mathrm{ANA}^{+}$groups and that the proportion of Treg cells was moderately correlated with the proportion of Tfh cells in all $\mathrm{ANA}^{+}$groups, suggesting similar attempts at immunoregulation. It is currently unknown whether the expanded Treg populations in any of the $\mathrm{ANA}^{+}$groups are functionally altered.

The nature of the immunologic changes seen in asymptomatic $\mathrm{ANA}^{+}$individuals suggests that abnormal activation of both $\mathrm{T}$ and $\mathrm{B}$ cells contributes to the generation of ANAs. While some of these immunologic changes may be driven by the elevated type I IFN seen in a subset of these individuals [27], increased B cell activation and decreased proportions of iNKT and IFN$\gamma$-producing $\mathrm{CD}^{+} \mathrm{T}$ cells were still seen in asymptomatic $\mathrm{ANA}^{+}$individuals with type I IFN within the normal range. Although we have not previously assessed cytokine-producing $\mathrm{T}$ cells in asymptomatic $\mathrm{ANA}^{+}$individuals, the iNKT findings observed in the current study recapitulate those seen in our previous study of asymptomatic first-degree relatives of patients with SLE, where we found an association between reduced levels of iNKT cells and ANA positivity [44]. In that study, we found that the levels of iNKT cells were significantly correlated between genetically related individuals in the same family suggesting that this was a heritable trait. Given the evidence that iNKT cells are involved in regulation of autoimmunity [72], these findings suggest that deficiencies of iNKT cells may predispose genetically susceptible individuals to the development of ANA positivity.

It is probable that the decreased proportion of peripheral blood IFN- $\gamma$-producing $\mathrm{CD}^{+}{ }^{+} \mathrm{T}$ cells observed in our study reflects chronic activation, which could arise either from migration into inflamed tissues [61] or exhaustion due to chronic activation [73]. Since altered activation of IFN- $\gamma$-producing $\mathrm{CD}^{+} \mathrm{T}$ cells is seen in asymptomatic $\mathrm{ANA}^{+}$individuals with normal levels of type I IFN and since we and others have found that elevated type I IFN typically follows autoantibody production, this observation 
suggests that activation of IFN- $\gamma$-producing cells temporally precedes type I IFN production in the evolution of ANAs. This concept has previously been proposed based upon the observation that elevated serum IFN- $\gamma$ temporally precedes increases in type I IFNs during progression to SLE [74].

The proportion of Th cells was also increased in asymptomatic $\mathrm{ANA}^{+}$individuals. In this study, we gated these cells as CXCR5 ${ }^{+} \mathrm{PD} 1^{\text {hi }}$, which in previous work have been shown to represent activated memory Tfh cells that are released into the circulation following germinal center-inducing immune responses $[49,75]$. Although activated memory Tfh have been shown to secrete IL-21, no differences in the proportion of IL-21-secreting $\mathrm{CD} 4^{+} \mathrm{T}$ cells were observed between groups, likely because activated memory Tfh only represent a small proportion of IL-21-secreting cells in the peripheral blood [76], precluding detection of significant differences.

As outlined previously, in asymptomatic $\mathrm{ANA}^{+}$individuals, the proportion of Tfh strongly correlated with PC5 score, suggesting a potential involvement of Tfh in autoantibody production. Consistent with this possibility, the proportion of Tfh was positively correlated with the ANA titer in asymptomatic $\mathrm{ANA}^{+}$individuals and with the number of autoantibody specificities in patients with SARD, and was also an independent predictor of serologic status in multivariate analysis including all $\mathrm{ANA}^{+}$subjects. These findings are compatible with previous work in mouse models indicating that the T-B collaboration within germinal centers is important in epitope spreading and production of high-affinity pathogenic autoantibodies $[77,78]$. Although type I IFN levels were also independently associated with the number of autoantibody specificities in the multivariate analysis, it is likely that they too act through this process, as type I IFNs have been shown to have a number of immunologic effects that enhance Tfh development and germinal center responses [65, 67, 68]. Notably, asymptomatic $\mathrm{ANA}^{+}$individuals who developed new SARD criteria over the subsequent 2 years had significantly higher type I IFN and a trend toward increased proportions of Th cells, suggesting that these processes also drive progression.

In many $\mathrm{ANA}^{+}$patients and patients with UCTD the cellular phenotypes examined could not be discriminated from those of patients with early SARD. This finding suggests that there are additional as yet undetermined immunologic events that dictate the onset of symptoms in SARD. Previous work has shown that the onset of symptoms in SARD is associated with increasing production of pro-inflammatory factors [79]; thus, there must be a change in the character of the immune response that results in the development of symptoms. Whether this is due to alterations in the amount, specificity, or character of autoantibodies, availability of autoantigens, nature of $\mathrm{T}$ cell help, or immunoregulatory function is currently unknown and is the focus of ongoing investigations.

\section{Conclusions}

Asymptomatic $\mathrm{ANA}^{+}$individuals and patients with UCTD have abnormal activation of their peripheral blood $\mathrm{B}$ and $\mathrm{T}$ cell compartments. The types of immunologic changes seen suggest that germinal centers are important in the generation of ANAs and that type I IFNs may enhance this process. Given the similarity between the immune abnormalities in these individuals and those with early SARD, some of the currently accepted cellular features of SARD appear to be associated with ANA production rather than the immunologic events that cause symptoms in SARD.

\section{Additional file}

Additional file 1: Table S1. Study participant characteristics. Figure S1. Proportion of $\mathrm{CD}^{+} 5^{+}$cells in the peripheral B cell subsets of $\mathrm{ANA}^{+}$ individuals with and without SARD. Figure S2. Plasma cell and plasmablast frequencies are unchanged in $\mathrm{ANA}^{+}$individuals with or without a SARD diagnosis. Figure S3. The majority of cellular phenotypes that differ between $\mathrm{ANA}^{+}$and $\mathrm{ANA}^{-}$groups do not vary with age. Figure S4. BAFF and type I IFN levels are increased in SARD patients. Figure S5. Spearman correlation matrix showing the association between cellular and selected serologic/cytokine phenotypes in UCTD patients. (DOCX 1697 kb)

\section{Abbreviations}

ANA: Anti-nuclear antibody; BAFF: B cell activating factor; ELISA: Enzymelinked immunosorbent assay; HC: Healthy control; IFN: Interferon; IL: Interleukin; iNKT: Invariant natural killer T; PBMC: Peripheral blood mononuclear cell; PC: Plasma cell; PCA: Principal component analysis; PMA: Phorbol-12-myristate-13-acetate; SARD: Systemic autoimmune rheumatic disease; SjD: Sjogren's Disease; SLE: Systemic lupus erythematosus; SSc: Systemic sclerosis; Tfh: T follicular helper; Treg: T regulatory;

UCTD: Undifferentiated connective tissue disease

\section{Acknowledgements}

Not applicable.

\section{Funding}

This study was funded by a Strategic Operating Grant from The Arthritis Society of Canada (grant number SOG-15-281). YB was the recipient of a Doctoral Fellowship from the Canadian Institutes of Health Research (CIHR) SRJ is supported by a CIHR Clinician Scientist Award, the Oscar and Eleanor Markovitz Fund for Scleroderma Research, and the Freda Fejer Fund for Scleroderma Research. KM was funded by Ontario Graduate and Queen Elizabeth II/Edward Dunlop Foundation Graduate Scholarship in Science and Technology Scholarships. DF is the recipient of a CIHR Master's Award. SR-S was funded by a Canadian Rheumatology Association Roche Summer Studentship. CL-M was the recipient of a Clinician-Scientist Salary Award from the Arthritis and Autoimmunity Research Centre of the University Health Network. JW is funded by The Arthritis Centre of Excellence of the University of Toronto and is the recipient of a Department of Medicine Merit Award.

\section{Availability of data and materials}

Supporting data are located in Additional file 1.

\section{Authors' contributions}

$S R J, A B, C L-M$, and JW were responsible for study conception and design. $Y B$, $\mathrm{N}-\mathrm{HC}$, SRJ, WH, KM, DF, BN, DB, SR-S, LL, ES, AB, CL-M, and JW were responsible for the acquisition of data. $Y B, N-H C, S R J, S R-S, E S, A B, C L-M$, and JW performed the data analysis and interpretation. All authors were 
involved in drafting the article or revising it critically for important intellectual content, and all authors approved the final version to be published.

\section{Ethics approval and consent to participate}

The study was approved by the Research Ethics Boards of the University Health Network (12-5455-BE) and Mount Sinai Hospital, and all participants signed informed consent.

\section{Consent for publication \\ Not applicable.}

\section{Competing interests}

The authors declare that they have no competing interests.

\section{Publisher's Note}

Springer Nature remains neutral with regard to jurisdictional claims in published maps and institutional affiliations.

\section{Author details}

${ }^{1}$ Krembil Research Institute, University Health Network, 60 Leonard Avenue, 5KD402, Toronto, ON M5T 2S8, Canada. ${ }^{2}$ Department of Immunology, University of Toronto, Toronto, ON, Canada. ${ }^{3}$ Division of Rheumatology, University Health Network, Toronto, ON, Canada. ${ }^{4}$ Department of Medicine, University of Toronto, Toronto, ON, Canada. ${ }^{5}$ Division of Rheumatology, Mount Sinai Hospital, Toronto, ON, Canada. ${ }^{6}$ Institute of Health Policy, Management and Evaluation, University of Toronto, Toronto, ON, Canada. ${ }^{7}$ Lakeridge Health Services, Oshawa, ON, Canada. ${ }^{8}$ Division of Rheumatology, Sick Children's Hospital, Toronto, ON, Canada. ${ }^{9}$ Department of Pediatrics, University of Toronto, Toronto, ON, Canada.

\section{Received: 2 August 2018 Accepted: 24 October 2018}

\section{Published online: 29 November 2018}

\section{References}

1. Alarcon-Segovia D, Alarcon-Riquelme ME, Cardiel MH, Caeiro F, Massardo L, Villa AR, Pons-Estel BA. Familial aggregation of systemic lupus erythematosus, rheumatoid arthritis, and other autoimmune diseases in 1,177 lupus patients from the GLADEL cohort. Arthritis Rheum. 2005; 52(4):1138-47.

2. Kallenberg CG. Overlapping syndromes, undifferentiated connective tissue disease, and other fibrosing conditions. Curr Opin Rheumatol. 1995;7(6): 568-73.

3. Reveille JD, Wilson RW, Provost TT, Bias WB, Arnett FC. Primary Sjogren's syndrome and other autoimmune diseases in families. Prevalence and immunogenetic studies in six kindreds. Ann Intern Med. 1984;101(6):748-56.

4. Rodriguez-Reyna TS, Alarcon-Segovia D. Overlap syndromes in the context of shared autoimmunity. Autoimmunity. 2005;38(3):219-23.

5. Arbuckle MR, McClain MT, Rubertone MV, Scofield RH, Dennis GJ, James JA, Harley JB. Development of autoantibodies before the clinical onset of systemic lupus erythematosus. N Engl J Med. 2003;349(16):1526-33.

6. Eriksson C, Kokkonen H, Johansson M, Hallmans G, Wadell G, RantapaaDahlqvist S. Autoantibodies predate the onset of systemic lupus erythematosus in northern Sweden. Arthritis Res Ther. 2011;13(1):R30.

7. Julkunen $\mathrm{H}$, Eronen M. Long-term outcome of mothers of children with isolated heart block in Finland. Arthritis Rheum. 2001:44(3):647-52.

8. Theander E, Jonsson R, Sjostrom B, Brokstad K, Olsson P, Henriksson G. Prediction of Sjogren's syndrome years before diagnosis and identification of patients with early onset and severe disease course by autoantibody profiling. Arthritis Rheumatol. 2015;67(9):2427-36.

9. Frandsen PB, Kriegbaum NJ, Ullman S, Hoier-Madsen M, Wiik A, Halberg P. Follow-up of 151 patients with high-titer U1RNP antibodies. Clin Rheumatol. 1996;15(3):254-60

10. Calvo-Alen J, Alarcon GS, Burgard SL, Burst N, Bartolucci AA, Williams HJ. Systemic lupus erythematosus: predictors of its occurrence among a cohort of patients with early undifferentiated connective tissue disease: multivariate analyses and identification of risk factors. J Rheumatol. 1996; 23(3):469-75.

11. Danieli MG, Fraticelli P, Salvi A, Gabrielli A, Danieli G. Undifferentiated connective tissue disease: natural history and evolution into definite CTD assessed in 84 patients initially diagnosed as early UCTD. Clin Rheumatol. 1998;17(3):195-201.
12. Danieli MG, Fraticelli P, Franceschini F, Cattaneo R, Farsi A, Passaleva A, Pietrogrande M, Invernizzi F, Vanoli M, Scorza R, et al. Five-year follow-up of 165 Italian patients with undifferentiated connective tissue diseases. Clin Exp Rheumatol. 1999;17(5):585-91.

13. Cavazzana I, Franceschini F, Belfiore N, Quinzanini M, Caporali R, CalzavaraPinton P, Bettoni L, Brucato A, Cattaneo R, Montecucco C. Undifferentiated connective tissue disease with antibodies to Ro/SSa: clinical features and follow-up of 148 patients. Clin Exp Rheumatol. 2001;19(4):403-9.

14. Bodolay E, Csiki Z, Szekanecz Z, Ben T, Kiss E, Zeher M, Szucs G, Danko K, Szegedi G. Five-year follow-up of 665 Hungarian patients with undifferentiated connective tissue disease (UCTD). Clin Exp Rheumatol. 2003;21(3):313-20.

15. Mosca M, Baldini C, Bombardieri S. Undifferentiated connective tissue diseases in 2004. Clin Exp Rheumatol. 2004;22(3 Suppl 33):S14-8.

16. Stahl Hallengren C, Nived O, Sturfelt G. Outcome of incomplete systemic lupus erythematosus after 10 years. Lupus. 2004;13(2):85-8.

17. Vila LM, Mayor AM, Valentin AH, Garcia-Soberal M, Vila S. Clinical outcome and predictors of disease evolution in patients with incomplete lupus erythematosus. Lupus. 2000;9(2):110-5.

18. Robertson JM, James JA. Preclinical systemic lupus erythematosus. Rheum Dis Clin N Am. 2014:40(4):621-35.

19. Munroe ME, Young KA, Kamen DL, Guthridge JM, Niewold TB, Costenbader $\mathrm{KH}$, Weisman MH, Ishimori ML, Wallace DJ, Gilkeson GS, et al. Discerning risk of disease transition in relatives of systemic lupus erythematosus patients utilizing soluble mediators and clinical features. Arthritis Rheumatol. 2017; 69(3):630-42.

20. Brito-Zeron P, Theander E, Baldini C, Seror R, Retamozo S, Quartuccio L, Bootsma H, Bowman SJ, Dorner T, Gottenberg JE, et al. Early diagnosis of primary Sjogren's syndrome: EULAR-SS task force clinical recommendations. Expert Rev Clin Immunol. 2016;12(2):137-56.

21. Koenig M, Joyal F, Fritzler MJ, Roussin A, Abrahamowicz M, Boire G, Goulet JR, Rich E, Grodzicky T, Raymond Y, et al. Autoantibodies and microvascular damage are independent predictive factors for the progression of Raynaud's phenomenon to systemic sclerosis: a twenty-year prospective study of 586 patients, with validation of proposed criteria for early systemic sclerosis. Arthritis Rheum. 2008;58(12):3902-12.

22. Valentini G, Marcoccia A, Cuomo G, Vettori S, ludici M, Bondanini F, Santoriello C, Ciani A, Cozzolino D, De Matteis GM, et al. Early systemic sclerosis: analysis of the disease course in patients with marker autoantibody and/or capillaroscopic positivity. Arthritis Care Res. 2014; 66(10):1520-7.

23. Hochberg MC. Updating the American College of Rheumatology revised criteria for the classification of systemic lupus erythematosus. Arthritis Rheum. 1997;40(9):1725.

24. van den Hoogen F, Khanna D, Fransen J, Johnson SR, Baron M, Tyndall A, Matucci-Cerinic M, Naden RP, Medsger TA Jr, Carreira PE, et al. 2013 classification criteria for systemic sclerosis: an American college of rheumatology/European league against rheumatism collaborative initiative. Ann Rheum Dis. 2013;72(11):1747-55.

25. Vitali C, Bombardieri S, Jonsson R, Moutsopoulos HM, Alexander EL, Carsons SE, Daniels TE, Fox PC, Fox Rl, Kassan SS, et al. Classification criteria for Sjogren's syndrome: a revised version of the European criteria proposed by the American-European Consensus Group. Ann Rheum Dis. 2002; 61(6):554-8.

26. Armstrong SM, Wither JE, Borowoy AM, Landolt-Marticorena C, Davis AM, Johnson SR. Development, sensibility, and validity of a systemic autoimmune rheumatic disease case ascertainment tool. J Rheumatol. 2017:44(1):18-23.

27. Wither J, Johnson SR, Liu T, Noamani B, Bonilla D, Lisnevskaia L, Silverman E, Bookman A, Landolt-Marticorena C. Presence of an interferon signature in individuals who are anti-nuclear antibody positive lacking a systemic autoimmune rheumatic disease diagnosis. Arthritis Res Ther. 2017;19(1):41.

28. Sato S, Fujimoto M, Hasegawa M, Takehara K. Altered blood B lymphocyte homeostasis in systemic sclerosis: expanded naive B cells and diminished but activated memory B cells. Arthritis Rheum. 2004;50(6):1918-27.

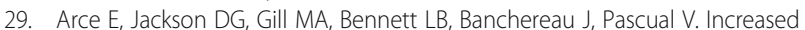
frequency of pre-germinal center B cells and plasma cell precursors in the blood of children with systemic lupus erythematosus. J Immunol. 2001; 167(4):2361-9.

30. Chang NH, McKenzie T, Bonventi G, Landolt-Marticorena C, Fortin PR, Gladman D, Urowitz M, Wither JE. Expanded population of activated 
antigen-engaged cells within the naive B cell compartment of patients with systemic lupus erythematosus. J Immunol. 2008;180(2):1276-84.

31. Jacobi AM, Odendahl M, Reiter K, Bruns A, Burmester GR, Radbruch A, Valet G, Lipsky PE, Dorner T. Correlation between circulating CD27high plasma cells and disease activity in patients with systemic lupus erythematosus. Arthritis Rheum. 2003;48(5):1332-42.

32. Jacobi AM, Reiter K, Mackay M, Aranow C, Hiepe F, Radbruch A, Hansen A, Burmester GR, Diamond B, Lipsky PE, et al. Activated memory B cell subsets correlate with disease activity in systemic lupus erythematosus: delineation by expression of CD27, IgD, and CD95. Arthritis Rheum. 2008;58(6):1762-73.

33. Odendahl M, Jacobi A, Hansen A, Feist E, Hiepe F, Burmester GR, Lipsky PE, Radbruch A, Dorner T. Disturbed peripheral B lymphocyte homeostasis in systemic lupus erythematosus. J Immunol. 2000;165(10):5970-9.

34. Szabo K, Papp G, Szanto A, Tarr T, Zeher M. A comprehensive investigation on the distribution of circulating follicular $T$ helper cells and B cell subsets in primary Sjogren's syndrome and systemic lupus erythematosus. Clin Exp Immunol. 2016;183(1):76-89.

35. Roberts ME, Kaminski D, Jenks SA, Maguire C, Ching K, Burbelo PD, ladarola MJ, Rosenberg A, Coca A, Anolik J, et al. Primary Sjogren's syndrome is characterized by distinct phenotypic and transcriptional profiles of IgD+ unswitched memory B cells. Arthritis Rheumatol. 2014;66(9):2558-69.

36. Bohnhorst JO, Bjorgan MB, Thoen JE, Natvig JB, Thompson KM. Bm1-Bm5 classification of peripheral blood $B$ cells reveals circulating germinal center founder cells in healthy individuals and disturbance in the B cell subpopulations in patients with primary Sjogren's syndrome. J Immunol. 2001;167(7):3610-8.

37. Hansen A, Odendahl M, Reiter K, Jacobi AM, Feist E, Scholze J, Burmester GR, Lipsky PE, Dorner T. Diminished peripheral blood memory B cells and accumulation of memory $B$ cells in the salivary glands of patients with Sjogren's syndrome. Arthritis Rheum. 2002;46(8):2160-71.

38. Wei C, Jenks S, Sanz I. Polychromatic flow cytometry in evaluating rheumatic disease patients. Arthritis Res Ther. 2015;17:46.

39. Streicher K, Morehouse CA, Groves CJ, Rajan B, Pilataxi F, Lehmann KP, Brohawn PZ, Higgs BW, McKeever K, Greenberg SA, et al. The plasma cell signature in autoimmune disease. Arthritis Rheumatol. 2014;66(1):173-84.

40. Cho YN, Kee SJ, Lee SJ, Seo SR, Kim TJ, Lee SS, Kim MS, Lee WW, Yoo DH, Kim N, et al. Numerical and functional deficiencies of natural killer T cells in systemic lupus erythematosus: their deficiency related to disease activity. Rheumatology (Oxford). 2011;50(6):1054-63.

41. Papp G, Horvath IF, Barath S, Gyimesi E, Sipka S, Szodoray P, Zeher M. Altered T-cell and regulatory cell repertoire in patients with diffuse cutaneous systemic sclerosis. Scand J Rheumatol. 2011;40(3):205-10.

42. Riccieri V, Parisi G, Spadaro A, Scrivo R, Barone F, Moretti T, Bernardini G, Strom R, Taccari E, Valesini G. Reduced circulating natural killer T cells and gamma/delta T cells in patients with systemic sclerosis. J Rheumatol. 2005; 32(2):283-6.

43. van der Vliet HJ, von Blomberg BM, Nishi N, Reijm M, Voskuyl AE, van Bodegraven AA, Polman CH, Rustemeyer T, Lips P, van den Eertwegh AJ, et al. Circulating V(alpha24+) Vbeta11+ NKT cell numbers are decreased in a wide variety of diseases that are characterized by autoreactive tissue damage. Clin Immunol. 2001;100(2):144-8.

44. Wither J, Cai YC, Lim S, McKenzie T, Roslin N, Claudio JO, Cooper GS, Hudson TJ, Paterson AD, Greenwood CM, et al. Reduced proportions of natural killer T cells are present in the relatives of lupus patients and are associated with autoimmunity. Arthritis Res Ther. 2008;10(5):R108.

45. Alexander T, Sattler A, Templin L, Kohler S, Gross C, Meisel A, Sawitzki B, Burmester GR, Arnold R, Radbruch A, et al. Foxp3+ Helios+ regulatory T cells are expanded in active systemic lupus erythematosus. Ann Rheum Dis. 2013;72(9):1549-58.

46. Golding A, Hasni S, Illei G, Shevach EM. The percentage of FoxP3+Helios+ Treg cells correlates positively with disease activity in systemic lupus erythematosus. Arthritis Rheum. 2013;65(11):2898-906.

47. Fonseca VR, Romao VC, Agua-Doce A, Santos M, Lopez-Presa D, Ferreira AC, Fonseca JE, Graca L. The ratio of blood $T$ follicular regulatory cells to $T$ follicular helper cells marks ectopic lymphoid structure formation While activated follicular helper t cells indicate disease activity in primary Sjogren's syndrome. Arthritis Rheumatol. 2018;70(5):774-84.

48. Verstappen GM, Nakshbandi U, Mossel E, Haacke EA, van der Vegt B, Vissink A, Bootsma H, Kroese FGM. Is the T follicular regulatory / T follicular helper cell ratio in blood a biomarker for ectopic lymphoid structure formation in Sjogren's syndrome? Arthritis Rheumatol. 2018;70(8):1354-5..
49. Schmitt N, Bentebibel SE, Ueno H. Phenotype and functions of memory Tfh cells in human blood. Trends Immunol. 2014;35(9):436-42.

50. Simpson N, Gatenby PA, Wilson A, Malik S, Fulcher DA, Tangye SG, Manku $\mathrm{H}$, Vyse TJ, Roncador G, Huttley GA, et al. Expansion of circulating T cells resembling follicular helper $T$ cells is a fixed phenotype that identifies a subset of severe systemic lupus erythematosus. Arthritis Rheum. 2010;62(1): 234-44.

51. Szabo K, Papp G, Barath S, Gyimesi E, Szanto A, Zeher M. Follicular helper T cells may play an important role in the severity of primary Sjogren's syndrome. Clin Immunol. 2013;147(2):95-104.

52. Osnes LT, Nakken B, Bodolay E, Szodoray P. Assessment of intracellular cytokines and regulatory cells in patients with autoimmune diseases and primary immunodeficiencies - novel tool for diagnostics and patient followup. Autoimmun Rev. 2013;12(10):967-71.

53. Szodoray P, Gal I, Barath S, Aleksza M, Horvath IF, Gergely PJ, Szegedi G, Nakken B, Zeher M. Immunological alterations in newly diagnosed primary Sjogren's syndrome characterized by skewed peripheral T-cell subsets and inflammatory cytokines. Scand J Rheumatol. 2008;37(3):205-12.

54. Szodoray P, Nakken B, Barath S, Gaal J, Aleksza M, Zeher M, Sipka S, Szilagyi A, Zold E, Szegedi G, et al. Progressive divergent shifts in natural and induced T-regulatory cells signify the transition from undifferentiated to definitive connective tissue disease. Int Immunol. 2008;20(8):971-9.

55. Dolff S, Abdulahad WH, Westra J, Doornbos-van der Meer B, Limburg PC, Kallenberg CG, Bij M. Increase in IL-21 producing T-cells in patients with systemic lupus erythematosus. Arthritis Res Ther. 2011;13(5):R157.

56. Dolff S, Bijl M, Huitema MG, Limburg PC, Kallenberg CG, Abdulahad WH. Disturbed Th1, Th2, Th17 and T(reg) balance in patients with systemic lupus erythematosus. Clin Immunol. 2011;141(2):197-204.

57. Fujii H, Hasegawa M, Takehara K, Mukaida N, Sato S. Abnormal expression of intracellular cytokines and chemokine receptors in peripheral blood T lymphocytes from patients with systemic sclerosis. Clin Exp Immunol. 2002; 130(3):548-56.

58. Kohriyama K, Katayama Y. Disproportion of helper T cell subsets in peripheral blood of patients with primary Sjogren's syndrome. Autoimmunity. 2000;32(1):67-72.

59. Sudzius G, Mieliauskaite D, Butrimiene I, Siaurys A, Mackiewicz Z, Dumalakiene I. Activity of T-helper cells in patients with primary Sjogren's syndrome. In Vivo. 2013;27(2):263-8.

60. Truchetet ME, Brembilla NC, Montanari E, Allanore Y, Chizzolini C. Increased frequency of circulating Th22 in addition to Th17 and Th2 lymphocytes in systemic sclerosis: association with interstitial lung disease. Arthritis Res Ther. 2011;13(5):R166.

61. van Woerkom JM, Kruize AA, Wenting-van Wijk MJ, Knol E, Bihari IC, Jacobs JW, Bijlsma JW, Lafeber FP, van Roon JA. Salivary gland and peripheral blood Thelper 1 and 2 cell activity in Sjogren's syndrome compared with non-Sjogren's sicca syndrome. Ann Rheum Dis. 2005;64(10):1474-9.

62. Niewold TB, Kelly JA, Kariuki SN, Franek BS, Kumar AA, Kaufman KM, Thomas K, Walker D, Kamp S, Frost JM, et al. IRF5 haplotypes demonstrate diverse serological associations which predict serum interferon alpha activity and explain the majority of the genetic association with systemic lupus erythematosus. Ann Rheum Dis. 2012;71(3):463-8.

63. Mackay F, Silveira PA, Brink R. B cells and the BAFF/APRIL axis: fast-forward on autoimmunity and signaling. Curr Opin Immunol. 2007;19(3):327-36.

64. Theofilopoulos AN, Baccala R, Beutler B, Kono DH. Type I interferons (alpha/ beta) in immunity and autoimmunity. Annu Rev Immunol. 2005;23:307-36.

65. Cucak H, Yrlid U, Reizis B, Kalinke U, Johansson-Lindbom B. Type I interferon signaling in dendritic cells stimulates the development of lymph-noderesident T follicular helper cells. Immunity. 2009;31(3):491-501.

66. Ittah M, Miceli-Richard C, Eric Gottenberg J, Lavie F, Lazure T, Ba N, Sellam J, Lepajolec C, Mariette X. B cell-activating factor of the tumor necrosis factor family (BAFF) is expressed under stimulation by interferon in salivary gland epithelial cells in primary Sjogren's syndrome. Arthritis Res Ther. 2006;8(2):R51.

67. Le Bon A, Thompson C, Kamphuis E, Durand V, Rossmann C, Kalinke U, Tough DF. Cutting edge: enhancement of antibody responses through direct stimulation of B and T cells by type I IFN. J Immunol. 2006;176(4):2074-8.

68. Su C, Duan X, Zheng J, Liang L, Wang F, Guo L. IFN-alpha as an adjuvant for adenovirus-vectored FMDV subunit vaccine through improving the generation of T follicular helper cells. PLoS One. 2013;8(6):e66134.

69. Chang NH, Li TT, Kim JJ, Landolt-Marticorena C, Fortin PR, Gladman DD, Urowitz MB, Wither JE. Interferon-alpha induces altered transitional B cell 
signaling and function in systemic lupus erythematosus. J Autoimmun. 2015:58:100-10

70. Slight-Webb S, Lu R, Ritterhouse LL, Munroe ME, Maecker HT, Fathman CG Utz PJ, Merrill JT, Guthridge JM, James JA. Autoantibody-positive healthy individuals display unique immune profiles that may regulate autoimmunity. Arthritis Rheumatol. 2016;68(10):2492-502.

71. Szodoray P, Nakken B, Barath S, Csipo I, Nagy G, El-Hage F, Osnes LT, Szegedi G, Bodolay E. Altered Th17 cells and Th17/regulatory T-cell ratios indicate the subsequent conversion from undifferentiated connective tissue disease to definitive systemic autoimmune disorders. Hum Immunol. 2013; 74(12):1510-8

72. Doherty DG, Melo AM, Moreno-Olivera A, Solomos AC. Activation and regulation of $B$ cell responses by invariant natural killer T cells. Front Immunol. 2018;9:1360.

73. Chihara N, Madi A, Kondo T, Zhang H, Acharya N, Singer M, Nyman J, Marjanovic ND, Kowalczyk MS, Wang C, et al. Induction and transcriptional regulation of the co-inhibitory gene module in T cells. Nature. 2018; 558(7710):454-9.

74. Munroe ME, Lu R, Zhao YD, Fife DA, Robertson JM, Guthridge JM, Niewold TB, Tsokos GC, Keith MP, Harley JB, et al. Altered type II interferon precedes autoantibody accrual and elevated type I interferon activity prior to systemic lupus erythematosus classification. Ann Rheum Dis. 2016;75(11): 2014-21.

75. Bentebibel SE, Lopez S, Obermoser G, Schmitt N, Mueller C, Harrod C, Flano E, Mejias A, Albrecht RA, Blankenship D, et al. Induction of ICOS+CXCR3 + CXCR5+ TH cells correlates with antibody responses to influenza vaccination. Sci Transl Med. 2013;5(176):176ra132.

76. Locci M, Havenar-Daughton C, Landais E, Wu J, Kroenke MA, Arlehamn CL, Su LF, Cubas R, Davis MM, Sette A, et al. Human circulating PD-1+CXCR3CXCR5+ memory Tfh cells are highly functional and correlate with broadly neutralizing HIV antibody responses. Immunity. 2013;39(4):758-69.

77. Degn SE, van der Poel CE, Firl DJ, Ayoglu B, Al Qureshah FA, Bajic G, Mesin L, Reynaud CA, Weill JC, Utz PJ, et al. Clonal evolution of autoreactive germinal centers. Cell. 2017;170(5):913-26 e919.

78. Schroeder K, Herrmann M, Winkler TH. The role of somatic hypermutation in the generation of pathogenic antibodies in SLE. Autoimmunity. 2013; 46(2):121-7.

79. Lu R, Munroe ME, Guthridge JM, Bean KM, Fife DA, Chen H, Slight-Webb SR, Keith MP, Harley JB, James JA. Dysregulation of innate and adaptive serum mediators precedes systemic lupus erythematosus classification and improves prognostic accuracy of autoantibodies. J Autoimmun. 2016;74:182-93.

Ready to submit your research? Choose BMC and benefit from:

- fast, convenient online submission

- thorough peer review by experienced researchers in your field

- rapid publication on acceptance

- support for research data, including large and complex data types

- gold Open Access which fosters wider collaboration and increased citations

- maximum visibility for your research: over $100 \mathrm{M}$ website views per year

At $\mathrm{BMC}$, research is always in progress.

Learn more biomedcentral.com/submissions 